\title{
RESIDENTIAL BUILDING MANAGEMENT SYSTEM FEATURES AND UNDERLYING FACTORS
}

\author{
Iveta PUĶĪTE ${ }^{1}$, Ineta GEIPELE ${ }^{2}$ \\ ${ }^{1,2}$ Riga Technical University, Latvia \\ iveta.pukite@rtu.lv \\ ineta.geipele@rtu.lv
}

\begin{abstract}
For the implementation of real estate management, in accordance with the legislative framework of good practice and quality management, a system is required that helps the processes to be arranged according to their fundamental values, criteria and functions. The study sets residential property management elements and factors influencing them. The significance of the topic is set by the developing industry and the requirement for quality and sustainable management model that includes all interested parties - owners, lessees, tenants, users on the one side, housing managers on the other and the state, local government and non-governmental organisations on the third side. The development of this sector as a whole depends on the quality of residential housing management process.
\end{abstract}

Keywords: Residential buildings, management, system.

\section{INTRODUCTION}

Management of real estate has the ownership responsibility imposed on real estate long-term existence, ensuring maintenance of the property, administering and documenting the processes related to real estate management. Residential building management is an issue for both Latvian and European countries where a large percentage of real estate constitutes the housing fund.

The aim of the present research is to determine the sets of residential house management elements and the factors influencing this process.

The management object is a real estate building and its area.

The study determines the importance of a factor that the management system is functioning in a certain micro and macro environments, which have their own indicators that directly and indirectly affect the management system and development.

Residential house management process is complex and multi-faceted. The problem in this sector is the fact that there is no united system for property managers to follow; as a result, there are rare discussions about effective management model that would be prone to a high-class service and the sustainable development of the property.

The main tasks of the study are the following:

1. To ascertain theoretical approaches by using scientific literature and other sources; 
2. To analyse the system of influencing factors of the residential property management elements and to collect the quantity data about findings of the object;

3. To draw a general conclusion and to work out improvement proposals for the system of residential property management.

\section{THEORETICAL ASPECTS OF THE ACTION OF THE SYSTEM OF THE RESIDENTIAL PROPERTY MANAGEMENT}

Residential property management system is a successful and effective management tool and is based on three core values (Fig. 1):

1. Interconnected set of elements;

2. This set creates a unified entirety;

3. Management process as a whole has its goals and achievable objectives specific to the residential property management sector.

After the study of the literature about dwelling houses, there is a conclusion there are a lot of studies about the market of the real estate, the efficiency of building power grid models and renewal possibilities. There are also some studies about legal aspects in connection with residential property management, but the system as whole of the residential property management is not investigated properly.

As a result, the authors give their opinion and propose the model of residential property management elements. The system, offered by the authors, consists of five essential elements: legal norms, information technology, technical condition, access to finance and psychological readiness (Fig. 1).

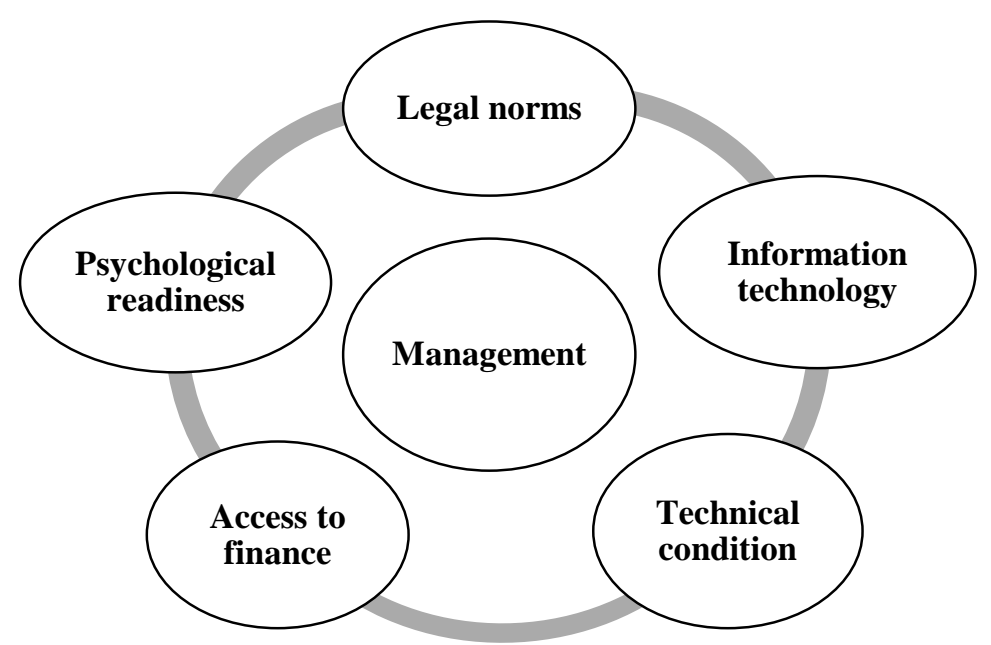

Fig. 1. Management system elements (made by the authors).

According to the studies performed by the researchers of Riga Technical University (Geipele et al., 2012), the residential house management sector affects society as a whole: starting with the state level and ending with the individual. Since Latvia has gained its independence, the residential house management has 
evolved chaotically. Residential house management comprises not only an economic content, housing and its management also have a social character. Residential house management was and always will be a topical issue as it affects basic needs of citizens. The services related to residential house management, including public utilities, are of the necessity, which have to be accessible to all levels of society. The facility management price and residential house maintenance costs are the most significant factors in the choice of the form of facility management and manager's appointment.

Since the interaction of privatization and economic situation in Latvia, there are discussions in our society about the problems of residential house management. The state is willing to put into practice heatproof isolation for buildings and use the EU fund, but people in Latvia - the residential house owners - are not sure whether to accept this decision or decline, and it is done for different reasons. After the privatization, all owners are responsible for maintenance of their flats, but there is a lack of comprehension of maintenance. In this case there is psychological and financial willingness of people to assume the responsibility of residential house management (Slava, and Geipele, 2012).

Professor J. Vanags points to economical and juridical characteristics that affects significant formation of the legal aspects of real estate. The great part of legal aspects has been established by different laws and liabilities, and by using different ways of real estate they regulate and determine the profit of property use - they take into account not only interests of owners, but also interests of society to retain healthy and safe living space (Vanags, 2010, p. 134).

There are a lot of studies about the efficiency of power grid system and effective instruments to improve it and other possibilities.

For example, the Lithuanian researchers remind that energy consumption in the world increases, so the measures in order to improve energy efficiency must be found. The aim of 2012/27/EU Energy Efficiency Directive is to decrease energy consumption for a final energy consumer by $1.5 \%$ every year, but there is no definition how this aim could be achieved by an individual member state. The European Union faces the increased volume of imported energy resources, climate change and the economic crisis. This leads to draw extra attention to energy efficiency, because the reduction of primary energy consumption directly reduces dependence on imported energy resources and increases energy security. Development of energy-efficient economics is conducive to innovative technological solutions and enhances the European Union's industrial competitiveness, promotes economic growth and creation of skilled workforce (Savickas, Savickiene, and Bielskus, 2015).

Every real estate is unique and there are no two identical residential houses. Because of that, it is very difficult to adapt a universal approach to residential house management. Only through comprehension of the role, all elements and mutual coherence, it is possible to secure the model of effective and qualitative residential house management.

The next element is property technical condition because its maintenance and viability depend on both - the legal framework that defines the works to be made and the regularity of maintenance and repairs, and the availability of information 
on the observance of the rules and responsibilities. Access to finance is one of the essential elements of the whole management system because the availability of financing is closely related to the solvency of customers and psychological readiness to make financial contributions into their own property maintenance and renewal.

The fourth element - the availability of financing includes both customer's solvency and the level of income, and the different types of subsidies (European Union's Structural Fund programmes etc.)

The fifth element - the psychological readiness. It is one of the essential elements of the whole management system, which affects how many residential homeowners will be willing to engage in the restoration of their property, implying the cooperation of both parties (client and manager).

Social capital perspective views the process as a set of interactions embedded within social structures that agents (building managers) help develop. One value of a social network is that well-connected members have more access to information than poorly connected members do. Therefore, a building manager can improve the effectiveness of decision making among flat owners by interconnecting them and maintaining the interconnections as a coordination mechanism (Sawyer et al., 2003).

A key component of strata or facilities management within residential buildings is the ability to react and respond to multiple resident issues in a reasonable timeframe. Resident concerns can be mitigated in large part from simply knowing they have been heard and that someone (i.e. Facilities Manager) is going to take action. Many issues can also be avoided by providing residents with some degree of control over their environment. Residents are often more tolerant of varying conditions when they understand how various systems, assets and equipment are supposed to perform and operate. It is critical that there be open and effective communication between residents and building managers to ensure the expectations of each are able to be understood and met. (Facility Management Association of Australia Ltd, 2012).

The authors conclude that the manager, who also performs a "social networking" maintenance function between the inhabitants of the house, can greatly improve the management efficiency of the process directly in psychological readiness and feedback elements.

\section{PRACTICAL RESEARCH PART}

The residential housing management sector of the Republic of Latvia has a number of laws and regulations. As a general law, it is necessary to mention the Civil Law, which regulates the case and law obligations. In turn, a special law is "Management of Residential Housing Law", which states the principles of management of residential buildings, residential houses management process of persons involved in the mutual relations, rights, duties and responsibilities, as well as state and local competence in this area. Therefore, from a legal point of view, industry regulation has developed a special law, which is respected by all the parties involved - the manager, the owners, and other users. 
As defined by the Civil Law: Every building owner must maintain public safety, he must keep his building in such a condition that any danger does not arise to the neighbours or people passing by, or any of its users (The Civil Law, 1937).

An apartment property is one of the most common types of the real estate in Latvia. It has appeared as a result of both the privatization of state or local government-owned residential buildings and the active purchasing of real estate properties using mortgage loans from 2006 to 2008 (Vanags, 2010; Vanags and Geipele, 2008).

According to the fact that the most important economic indicators, which are used to characterise the economic situation in the country, are economic growth, employment and price levels, the authors in the present research point out different measurements related to the level of unemployment, Gini coefficient, labour market payment, heating expenses, residential house management expenses. Environmental economic factors influence the management processes when the economy is healthy, it improves the management processes.

People with different understanding of property and economic approach became owners of multi-story apartment houses both as a result of privatization and mortgage lending process. For the former tenants, the legal status of the apartment owner is associated more with exclusive benefits and less with property related duties and responsibilities (Geipele et al., 2012).

Studying the economic activity indicators in the country, according to the data provided by the Central Statistical Bureau, the unemployment rate in the period from 2009 to 2014 was gradually decreasing (see Table 1). The highest unemployment rate was in 2010 when the country suffered from economic crisis, while in 2014 it decreased by $8.70 \%$, making up only $10.8 \%$. Such positive macroeconomic changes affect management processes, as with the improvement of the economic situation, consumers' ability to pay increases.

Table 1. Unemployment Rate in Latvia (\%) during the period from 2009-2014. Data source: Central Statistical Bureau of Latvia

\begin{tabular}{|l|r|r|r|r|r|r|}
\hline & $\mathbf{2 0 0 9}$ & $\mathbf{2 0 1 0}$ & $\mathbf{2 0 1 1}$ & $\mathbf{2 0 1 2}$ & $\mathbf{2 0 1 3}$ & $\mathbf{2 0 1 4}$ \\
\hline $\begin{array}{l}\text { The proportion of unemployed } \\
\text { economically active population \% }\end{array}$ & 17.5 & 19.5 & 16.2 & 15 & 11.9 & 10.8 \\
\hline
\end{tabular}

Economic factors are among the most significant ones, affecting the management processes. These factors are associated with demand management in the economy; they affect all the other factors and human behaviour.

Such a large proportion of job seekers, especially as it was in 2009-2010, gives a sign of problems in the labour. Such negative signs seriously affect management processes, as the negative trends in the field of employment arise, management processes also suffer because of the population, who cannot find work, have problems with paying for management services. Latvia has a high social inequality characterised by the increased Gini coefficient, which characterises income inequality. Latvian Gini coefficient in 2009 was $35.9 \%$, but 
in 2013 it was $35.5 \%$. This indicates that there were no significant changes in five years. Eurostat data from 2004 to 2012 shows different inequality indicators for the dynamics in the Baltic States. Despite the Gini index decline from $37.5 \%$ in 2008 to $35.2 \%$ in 2012, Latvia remains with the highest Gini index value in the European Union (SEB Bank, 2014).

According to the data provided by the Central Statistical Bureau of Latvia, the average Latvian household heating expenditures in 2013 (including hot water supply) were $€ 54.95$ per month, which represented $7.5 \%$ of total household monthly budget. From 2006 to 2013, heating expenses nearly doubled, while the share of household's budget increased by $2.5 \%$. Since 2010 , spending growth has been relatively small, but the proportion remained unchanged (Central Statistical Bureau of Latvia, 2015).

The heating expenses are considerably higher in urban areas than in rural areas. Rural households mainly use biomass for heating, while in urban areas the majority of district heating systems use fossil fuels, which are comparatively more expensive (Ministry of Economics, 2015).

Over the past few years, the Latvian economy is going upwards; the country is recovering from the economic crisis. In the 2 nd quarter of 2015, the average gross monthly wage in the country was $€ 815$, according to the Central Statistical Bureau. Compared to the previous year's second quarter, it grew by $6.9 \%$, slightly ahead of the annual growth rate $6.3 \%$ of this year's first quarter (Central Statistical Bureau of Latvia, 2015).

An important factor, in ensuring the positive management processes, is the income level; as a result, the population makes savings, which can be invested in housing management or process improvement.

The amount of management fee, the economic justification and the need for savings are essential aspects of ensuring successful management. Researchers of Riga Technical University (Geipele et al., 2012) have been studying the management fee formation principles. Their studies indicate that in order for the apartment owner to be able to assess property maintenance costs of his apartment and to understand price formation mechanism, the owner should be aware of the activities that are necessary to be provided in order to ensure the facility management and maintenance of the multi-story apartment house and understand the development of costs. The residential property maintenance costs consist of three parts: the actual share of the residential property, including maintenance costs of a particular apartment marked in the inventory file; the utility services; and maintenance costs of the share of co-ownership of the residential property or the price formation mechanism of the facility management service (Geipele et al., 2012).

Multi-story apartment buildings with 3 or more apartments, altogether 20753 houses, from which to only 4709 or $20 \%$ of the total number of houses facility management service is provided. If $86 \%$ of the apartments are privatized, then it should be highlighted that only $20 \%$ of residential buildings are privatized (Geipele et al., 2012).

This indicates that the apartment owners who have purchased these apartments as a property are either very inactive or there is nothing that motivates 
them to take over the house in their possession, or they are satisfied with the current situation when the apartment owners may apply to the local municipality and request the repair of the deemed share of their house and require to provide facility management.

Currently, the Law on Value Added Tax (further - VAT) is establishing exceptions where service is not subject to VAT. One of these services is residential management service payment in accordance with the management agreement. In turn, with 1 January 2016 changes in the law will be carried out, because the government has approved next year's budget, and in 2016 the house managers of apartment houses will charge larger bills. Housing management services will apply $21 \%$ VAT, which so far has not been applied.

Justification for this fee increase is a factor that Latvia as an EU Member State should ensure the European Union's implementation of the legislation into the national legislation. According to Directive 2006/112 / EC on the common system of value added tax (hereinafter - the Directive) Article 2, Paragraph 1, "c", VAT supply of services for consideration within the territory of a Member State shall be carried out. Directive IX in the "Exemptions" from 131 to 165 includes the transactions of supply of goods or services free of VAT. In addition, Directive 384 determines where Latvia has the right to certain specific transactions from VAT after its accession to the European Union. Residential house management service is not mentioned in the transactions covered by the Directive and is not exempted from VAT.

Given that Latvia is an EU Member State, the law binds it. As a result, management fee has to apply a value added tax, which in turn will lead to a rise in price of the cost of housing. For taxpayers and residents to prepare for changes to the VAT treatment of the residential house management service, those amendments should come into force no earlier than 1 July 2016.

Table 2. The Management Fee (made by the authors)

\begin{tabular}{|c|c|c|}
\hline \multirow{2}{*}{$\begin{array}{c}\text { The management fee, exclusive of VAT, } \\
\text { EUR/ } \mathbf{m}^{\mathbf{2}}\end{array}$} & \multicolumn{2}{|c|}{ The management fee with VAT EUR $/ \mathbf{m}^{\mathbf{2}}$} \\
\cline { 2 - 3 } & $\mathbf{2 1 ~ \%}$ & $\mathbf{1 2} \%$ \\
\hline 0.36 & 0.44 & 0.40 \\
\hline 0.38 & 0.46 & 0.43 \\
\hline 0.45 & 0.54 & 0.50 \\
\hline 0.50 & 0.61 & 0.56 \\
\hline
\end{tabular}

As we can see from Table 2, applying VAT to residential home management service leads to an essential increase in expenditure of citizens. In turn, this means that the number of debtors can grow. In applying VAT the management fee can increase till $5 \%$ (see Table 2). If the government had applied the reduced rate of VAT $(12 \%)$, an increase would be about $4.2 \%$.

Another price increase may have a negative impact on other elements of the management system - building technical condition and psychological readiness. The situation with apartment houses built during the Soviet time deteriorates, thus threatening inhabitants of the house. The only solution to this situation is building 
renovation and insulation. However, one of the major obstacles to why there is no active Latvian apartment building renovation and insulation is inhabitant's difficulties to make decisions.

According to the data provided by the Ministry of Economics, in Latvia there are around 1 million houses, from which $69 \%$ are multi-story family homes. Most of these houses were built before the restoration of independence. They are characterised by high structural and building depreciation, as well as low energy efficiency. According to the information provided by the Ministry of Economics, until the 1st quarter of 2015, 535 projects financed by ERAF were completed financing 43.4 million EUR. New contracts settled for 324 ERAF financed projects, funding up to 32 million. Until the 1st quarter of 2015, beneficiaries received ERAF funding up to 43 million (Ministry of Economy, 2014).

In spite of the previous year's apartment buildings energy efficiency improvement measures, currently only about $6 \%$ of the Latvian apartment buildings comply with the building heating requirements of the Latvian regulatory enactments. The Latvian government intends to continue providing support for improving energy efficiency of apartment houses in 2014-2020 during the EU fund programming period.

The uncertain energy efficiency project investment payback period can be mentioned as one of the negative aspects. After EM calculations, the average energy efficiency project payback period is 22-23 years (without regard to fundraising costs). During 2007-2013 programming period, EU funds support program project had to be approved by LIAA agency, and only then the banks would consider giving out commercial loans for the project. Consequently, it was not previously known whether the project would pay off, because the interest rate of the loan was unknown (Ministry of Economy, 2014).

Thus, it would be necessary to think about building energy models that would allow accurately predicting the expected savings. Building energy models are created for various reasons, including energy usage predictions. Often when energy model is created, the question comes up whether the results are reasonable. The accuracy of model can only be tested comparing actual utility bills to predicted energy consumptions. A very important step in this process is to adjust actual bill data because of differences of actual and assumed weather conditions. Linear regression (with data normalization) method proved to account for majority of observed differences (Gould and Hawkins, 2015).

Energy efficiency models could be used to check how accurately used heat technical calculation methodology is capable foreseeing demand after renovation. Prediction accuracy is very important for the adoption of investment decisions.

An important factor in residential property management aspect of the process is the development of information technology. Telecommunications contributes to national and public life scope; globalisation increases the chance to establish contacts, to conduct business, to carry out other activities without central government mediation (Latvian Long-Term Economic Strategy, 2001).

Information and technology of communication level of development enable economic agents to be interconnected in any sphere of activity on a global scale. There are new activities and the development of regulations based on overall 
economic entity's ability to access information and adapt it. Rapid technology changes, development of IT are related to changes in the products themselves and in their production. An increasingly important role in the competitiveness of goods and services is played by their quality and compliance with environmental protection requirements. Use of information technology in the economic activity allows applying more efficient production factors contributing to higher productivity.

Sawyer et al. (2003) present two perspectives on ICT use in real estate field, and study the role of information technology. Both perspectives are complementary and offer unique and valuable insights into industry's core processes. The first perspective focuses on the cost and economics of transactions (IT availability/ finance), the second on how transactions are embedded in and affected by their social context (psychological readiness). The social structures of interest to us within the present research are those sets of relationships that help define the way of residential multifamily building management and maintenance.

Buildings vary widely among numerous dimensions (size, location, technical condition, owners' requests, etc.), which makes them hard to describe succinctly and increases their asset. Researchers have considered additional factors within the transaction-cost framework and come up with four generic coordination structures (Sawyer et al., 2003).

\section{CONCLUSION AND RECOMMENDATIONS}

All five elements are interrelated. Management services are provided based on rules (Latvian legislation and EU directive regulations). In order for the law regulation to be informed of all the parties involved, it is necessary to develop a good exchange of information environment in which it would be possible to provide interested persons with both common law regulations and the direct exchange of information between the client (the owners / lessees / tenants) and service providers.

The research results show that the residential system of property management success is dependent on the micro and macro environmental impact, as well as their mutual synergies. The management system is essentially a number of elements of the mutual relationship that affects the technological and economic, as well as political and psychological aspects.

Property management involves the processes, systems and manpower required to manage the life cycle of all acquired property as defined above, including acquisition, control, accountability, responsibility and maintenance.

Introducing $21 \%$ of VAT on services of residential house management will lead to the mutilation of residential house management market. There are some possibilities for small offices to offer their services for residential house management free of VAT charge and that is cheaper than services from other professionals. As a result, there might be chaos and misunderstanding of the market of the residential house management. There might be the problems with tax administration, mutilation of the market of the residential house management and diminishing of quality. 
There is no possibility to cash $100 \%$ of charge of residential house management in Latvia. There are a lot of neighbours with debts who have not paid their bills for their property. There is no possibility to charge $100 \%$ of VAT. When the bill is written out about residential house management, the manager has to pay VAT according to the bill, but the level of encashment never is $100 \%$. There are two scenarios: first, the lacking sum of money manager pays off from the resources of savings - neighbours' instalments and that is in contradiction with the law of residential house management. The second scenario - the manager does not deposit VAT in the budget and, as a result, there will be the charge of the interest for delay and the increase of the instalments for solvent neighbours or the solvent manager.

To ensure the sustainable development management system, the authors put forward the following proposals:

The government has to issue the political resolution about the diminishing VAT for the management services, thereby not imposing additional payment to inhabitants. We have to lower the risk for companies not to have any excessive finance to pay the advance taxes; therefore, the government has to determine the longer period for the payment of VAT, outstanding accounts that have lasting delays and legal proceedings are taken against them.

To improve the energy efficiency measures of quality performance, it is necessary to develop competence centres, which provide apartment owners and their authorised persons access to guidance for planning, preparation and implementation of the financial aspect.

It is necessary to develop the energy efficiency calculator, where apartment owners and authorised persons would be able to make estimates of the foreseeable implementation of energy efficiency measures and payment amount after crediting.

The obtained research results point to the need for further study of residential housing management system, the influencing elements of the housing life, as well as the maintenance of an adequate legal framework in the country.

\section{REFERENCES}

Central Statistical Bureau of Latvia (2014). Statistic database. Retrieved from http://www.csb.gov.lv/ dati/statistikas-datubazes-28270.html

Geipele, I., Geipele, S., Plavina, B., Stamure, I. (2012). Pricing Peculiarities of Apartment House Management in Latvia. 7th International Scientific Conference Business and Management 2012. Selected Papers, Lithuania, Vilnius, May 10-11, 2012. 1075-1082. ISSN 2029-4441, e-ISSN 2029-929X. http://dx.doi.org/10.3846/bm.2012.137

Geipele, S., Geipele, I., Slava, D., Stāmure, I. (2012). Social, Economic and Legal Problems of Housing Management in Latvia. The 7th International Scientific Conference "Business and Management 2012": Selected Papers, Lithuania, Vilnius, 10-11 May, 2012. Vilnius Gediminas Technical University: VGTU Press "Technika", 2012, 631-638. ISBN 978-609-457-116-9. ISSN 2029-4441, e-ISSN 2029-929X. http://dx.doi.org/10.3846/bm.2012.082

Gould, S, Hawkins, M. (2015) Modeling Multifamily Buildings with eQuest: A Case Study of Prediction versus Reality. ASHRAE Transactions. 2015, 121(1), p1-8.

Facilities Management Good Practice Guide. Facility Management Association of Australia Ltd. 2012. ABN: 57003551 844. Retrieved November 20, 2015, from https://www.melbourne.vic.gov.au/ Sustainability/WhatCanIDo/Documents/Facilities_Mgt_MUR_Guide.pdf

Legislation of the Republic of Latvia (1937). Latvijas Republikas Civillikums. Lietu tiesības [The Civil Law of the Republic of Latvia, Part 3.]. Retrieved September 8, from http://likumi.lv/ doc.php?id=225418 
Legislation of the Republic of Latvia (2015). Dzīvojamo māju pārvaldīšanas likums [Law On Administration of Residential Houses]. Retrieved September 2, 2015, from http://likumi.lv/ ta/id/193573-dzivojamo-maju-parvaldisanas-likums

Legislation of the Republic of Latvia (1937). Latvijas ilgtermina ekonomiskā stratēgija [Latvian long-term economic strategy.]. Retrieved September 12, from http://likumi.lv/doc.php?id=54441

Ministry of Economcs, 2015. Ekonomikas ministrija, Daudzdzīvokḷu māju energoefektivitātes paaugstināšanas finanšu pieejamības Ex ante izvērtējums. Retrived from http://kom.esfondi.lv/ Shared\%20Documents/DMS_ExAnte_26022015.docx

Sawyer, S., Crowston, K., Wigrand, R.T., Allbritton, M. The social embeddedness of Transactions: Evidence from the Residential real - Estate Industry. The Information Society, 19(2), 135-154, http://dx.doi.org/10.1080/01972240309460

SEB bank. Latvijā ir lielākā nevienlīdzība ienākumu sadalē starp Baltijas valstīm, 2014. Retrieved September 11, from http://seb.lv/lv/about/press-centre/press-releases/y2014/maijs/15052014/

Slava, D., Geipele, S. (2012). Legal and Economic Problems of Housing Management in Latvia. Economics and Business, 22, 144-153. ISSN 1407-7337, e-ISSN 2255-8756.

Savickas, R., Savickiene, R., Bielskus, J. (2015). Technical measures to decrease heat energy consumption of final customer in multi - apartment buildings according to energy efficiency directive. Science - Future of Lithuania / Mokslas - Lietuvos Ateitis, 7(4), ISSN 2029-2341, eISSN 2029-2252. http://dx.doi.org/10.3846/mla.2015.822

Vanags, J., (2010). Nekustamā īpašuma ekonomika. Monograph. Rīga: Riga technical University. ISBN 978-9934-10-020-8.

Vanags, J., Geipele, I. (2008). Latvijas tautsaimniecība un būvniecības nozares attīstības ietekme uz nekustama ì íašuma tirgu. [Latvian economy and the impact of the development of construction sec-tor to the real estate market]. Monograph. Riga: RTU Publishing house. 196 p.

\section{AUTHORS’ SHORT BIOGRAPHY}

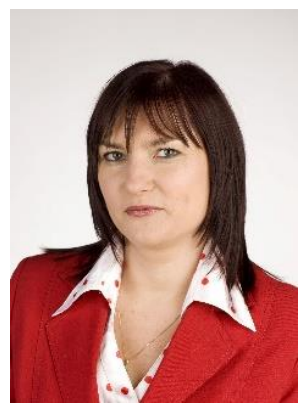

Iveta Puḳite, Mg. sc., Researcher at Riga Technical University, Faculty of Engineering Economics and Management; PhD student at RTU. Iveta Pukite has acquired higher education at the University of Latvia - Academic Master's degree in Management Sciences. She is a Lecturer of the College of Law as well. Now she is the Head of Real Estate Management Department at Ltd. Ādažu Namsaimnieks. She has participated in several scientific conferences. Research focus: socially responsible housing lifecycle of the management system.

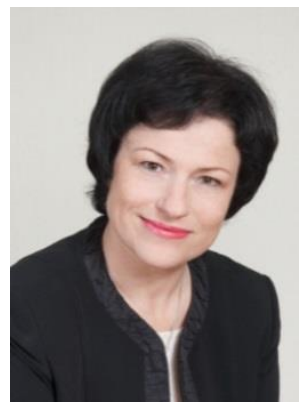

Ineta Geipele is the Professor at the Faculty of Engineering Economics and Management, the Director of the Institute of Civil Engineering and Real Estate Economics, the Head of the Chair of Civil Construction and Real Estate Economics and Management at Riga Technical University (RTU), Latvia. She has earned the Doctor's degree of Economics and Master's degree of Economics at RTU. Her professional skills are improved in Austria, Germany Denmark and England. She is the author and co-author of more than 284 scientific publications. Her current research interests are focused on sustainability development problems of real estate market, construction industry, including land use management and institutional economics. Ineta Geipele is an expert in management science of the Latvian Council of Science; Senior Member of the International Economics Development Research Centre (IEDRC); Member: of the International Society for Ecological Economics, of the EURO Working Group "OR in Sustainable Development and Civil Engineering (ORSDCE)", of Industrial Engineering and Operations Management (IEOM) Society "Achieving and Sustaining Operational Excellence"; a Board Member: of the FIABCI-Baltic Multinational Chapter, of the Cunfte of the Facility Management of Latvian Housing, a Member of the Latvian Union of Civil Engineers etc. 